\title{
Miranda
}

Revue pluridisciplinaire du monde anglophone /

Multidisciplinary peer-reviewed journal on the English-

speaking world

23 | 2021

Modernist Exceptions

\section{A Nurse in the Great War: The Exceptional Voice of Mary Borden}

Isabelle Brasme

OpenEdition

Journals

Electronic version

URL: https://journals.openedition.org/miranda/42228

DOI: 10.4000/miranda.42228

ISSN: 2108-6559

Publisher

Université Toulouse - Jean Jaurès

Electronic reference

Isabelle Brasme, "A Nurse in the Great War: The Exceptional Voice of Mary Borden", Miranda [Online],

23 | 2021, Online since 11 October 2021, connection on 29 November 2021. URL: http:// journals.openedition.org/miranda/42228 ; DOI: https://doi.org/10.4000/miranda.42228

This text was automatically generated on 29 November 2021.

\section{(c) (i) (3)}

Miranda is licensed under a Creative Commons Attribution-NonCommercial-NoDerivatives 4.0 International License. 


\title{
A Nurse in the Great War: The Exceptional Voice of Mary Borden
}

\author{
Isabelle Brasme
}

\section{Introduction}

1 During the First World War, the figure of the nurse was marked with a paradoxical tension: on the one hand, the nurses caring for the wounded on the various fronts of the war were idealised as avatars of the Virgin Mary, bent over the soldiers sacrificed to the nation. On the other hand, over the course of the war and for the several subsequent decades, the nurses' accounts of their experience just behind the front lines -through private letters, diaries, as well as through texts intended for publicationtended to be erased from collective memory; nurse writings were generally considered as inferior in terms of testimonial value to those produced by the soldiers, who were regarded as the only legitimate actors of the war. Recent research, however, has been paying closer attention to the contribution of women, and particularly of nurses, to the war effort; yet as will be developed below, little consideration has been given to the specific form in which they wrote of their experience.

2 This essay centres on the experience and literary testimony of a particular figure in the landscape of World War I nursing that is outstanding on a variety of counts: Mary Borden, an American millionaire who single-handedly established and funded the only hospital unit on the Franco-Belgian front that wasn't under the control of the Red Cross. This exceptional stance seems to have had a direct impact on her writing. Whilst Borden was socially active within the avant-garde London literary scene before 1914, her own pre-war novelistic writing tended towards a conventional form; however, her prose and verse took on a strikingly innovative turn during the war. My attempt will be to delineate how Borden's war writings set themselves at odds with existing cultural and aesthetic norms. This paper will first outline the unique position held during the war by Borden and her field hospital; this exceptional situation, as we shall then realise, is reflected in the distinctiveness of the collection of fragments that she wrote 
at the front, The Forbidden Zone. Finally, I propose to examine at closer range the question of representation in Borden's war writing, which I wish to argue is one of the major though overlooked reasons for its disregard when it was published. Beyond gender issues or questions of traumatic writing, what emerges out of Borden's disjointed sketches is a phenomenology of the experience of war-an experience that was radically unfamiliar due to its unprecedented nature, and was therefore sensed as exceptional. This phenomenology develops through a geography of isolation and estrangement, and through Borden's spectral mode of writing.

\section{Borden's Hôpital chirurgical mobile $n^{\circ} 1$}

3 When World War I broke out, Mary Borden had already published her first two novels, The Mistress of Kingdoms and Collision, in 1912 and 1913 respectively. Both had a marked feminist perspective, and the latter novel, set in India, dealt with questions of race and colonisation in a strongly satirical tone that anticipated Forster's A Passage to India (1924). Yet the writing style and the linear narratives were not markedly innovative. Both novels had received favourable reviews, and Borden was indeed active on the London literary scene, using her considerable wealth to entertain fellow artists such as Ford Madox Ford, E. M. Forster, and Wyndham Lewis-with whom she had a brief affair just before the war broke out. She also actively supported female suffrage, and even had a brief spell as a suffragette in 1913, when she flung stones at the Treasury Building during a protest, crashed a window, and spent five days in prison as a result. When the war broke out, Borden was living in London and was pregnant with her third child; but as soon as she was well enough to travel, in early 1915, and her daughter not being quite two months old, she set off on her own for France to serve as a nurse. She was trained on the spot, in a makeshift hospital set up in the casino at Malo-les-Bains, which created an incongruous backdrop for the suffering and death of soldiers. Borden highlighted this oxymoronic situation through a process of relentless defamiliarisation in one of her fragments, "The Beach", using the voice of a wounded soldier:

They've a gala night in our casino whenever there's a battle. Funny sort of place. You should watch the motors drive up then. The rush begins about ten in the evening and goes on till morning. Quite like Deauville the night of the Grand Prix. You never saw such a crowd. They all rush there from the front, you know-the way they do from the racecourse-though, to be sure, it is not quite the real thing-not a really smart crowd. [...] Still, our crowd here aren't precisely wasters. Gamblers, of course, down and outs, wrecks-all gone to pieces, parts of 'em missing, you know, tops of their heads gone, or one of their legs. When they take their places at the tables, the croupiers-that is to say, the doctors-look them over. [...] Some of them have no faces. (Borden 46)

4 The speaker here is a crippled soldier, addressing his lover, whose loveliness, wholeness, and immunity from the trauma of combat and trench life he can't help resenting. The sustained metaphor exploiting the incongruity of the casino's transformation into a hospital is deftly managed, with a gradation in the simile: the description first deploys double entendre through the words "gala night", "funny", "motors", "rush", "crowd", that may make the addressee wonder momentarily whether the scene described is not really that of a casino night. The pivotal shift towards a more explicit-and gruesome-meaning is initiated by the word "front", and is made complete when the phrase "wrecks-all gone to pieces-" is no longer figurative, but to be taken at face value: "parts of "em missing". The reversal is made complete through the affected 
correction "the croupiers-that is to say, the doctors", and the final horror inherent in the phrase "some of them have no faces". This shift from the lexical field of gambling and frivolousness to that of the war hospital and the wounded soldiers reinforces the abjection of the scene described; this defamiliarizing process serves as a tool to exert violence onto the audience or the reader, relentlessly addressed in the text through the phrases "you should watch", "you never saw", "you know", "of course." The matter-offact tone of the wounded soldier aims at confronting the audience and reader to the cognitive gap between his own jaded experience of the mangled bodies of the war and their-our-shock at the description.

5 The story of Borden's hospital is itself remarkable. Taking on a nursing role as an American or a British woman was no straightforward task in the early months of the war. As Jane Conway points out in her biography of Mary Borden, "during the first year of the war political, military and social resistance to women's involvement at the front made it extremely difficult for them to take an active role" (Conway 42). All of the other British women who offered to set up hospital units at the front were turned down by the British authorities and "told to go home and sit still" (Conway 42). This explains why Borden, along with many other American and British women, volunteered to nurse French soldiers. However, nurses caring for French soldiers on the Franco-Belgian front were under the command of the Croix-Rouge française, and the French nursing officers looked down at their recruits from Britain and Northern America, going so far as to impede their work as carers (Conway 41). Borden eventually circumvented the nursing authorities, and wrote directly to General Joseph Joffre, asking him for permission to found and lead a hospital that would be under the direct authority of the French Army, and not of the Croix-Rouge. Joffre agreed, and Borden was thus able to establish the Hôpital chirurgical mobile ${ }^{\circ} 1$, which became operational in July 1915 . The hospital was set outside the village of Rousbrugge near Ypres, only eleven kilometres behind the firing line. In 1916, during the Somme offensive, Borden set up a new hospital at Braysur-Somme, l'Hôpital d'évacuation, five kilometres behind the line; with its two thousand beds, it was the largest military hospital in the French Army (Conway 50).

Borden's field hospital was unique in several regards. Intriguingly, when searching the hospital archives for the war, no Hôpital chirurgical Mobile $n^{\circ} 2$, or 3, can be found: this number 1 has thus come to signify singularity rather than mere precedence in a series of other such mobile hospitals. Borden's hospital remained one of the most independent nursing units of the First World War. With a $5 \%$ mortality rate, it also boasted the lowest mortality rate on the entire front, and was called "le petit paradis des blessés" by the soldiers-to the point that the wounded expressly asked to be sent there (Conway 47). It was therefore outstanding on a number of counts. More importantly for this article, there seems to have existed a correlation between the independent status of Borden's unit and the number of testimonies that were written by nurses operating in her hospital: in her study Nurse Writers of the Great War, Christine Hallett remarks: "It would appear that those nurses who worked most independently were the ones who were also most likely to write memoirs and war narratives" (Hallett 2016, 16). Ellen La Motte, a professional nurse in Borden's hospital, published her antipropagandist memoir, The Backwash of War, in 1916, although its uncompromising descriptions caused it to be immediately censored both by British and American authorities. Maud Mortimer, who also volunteered at the Hôpital chirurgical mobile, authored A Green Tent in Flanders (1918), which appears to be directly inspired from 
Borden's hospital, although no names are given. The Canadian Agnes Warner, Borden's Head Nurse, wrote letters to her family that were published by her mother and sisters, unbeknownst to their author, as My Beloved Poilus in 1917 (Hallett 2016, 9). Finally, Borden herself wrote of her immediate experience through fragments of prose and poetry that came to be published in 1929 as The Forbidden Zone, and which I now propose to examine more closely.

\section{The Forbidden Zone: a singular volume}

The publication history of this volume is itself a token of its peculiarity. In 1917, Borden published in the English Review three poems and a prose sketch that she came to include in The Forbidden Zone. She submitted the whole manuscript of The Forbidden Zone for publication in the same year. The publishers at Collins were ready to buy it, but the military censors demanded that several passages be removed, for fear of damaging morale; a French translation of the book was treated likewise by French censorship (Conway 77). Borden, however, refused to edit these passages out of her texts, as she sensed they would impair the integrity of her account. The volume was eventually published in 1929, when the risk of damaging morale was long gone, with the addition of five pieces that were written after the war. The Forbidden Zone was out of print from 1930 to 2008, when it was finally re-edited by Hazel Hutchison and published by Hesperus Press; this re-edition, however, omits all of the poems, which formed the third section of Borden's original collection. To this day the volume as a whole is therefore out of print. The poems were published separately by Paul O'Prey, in 2015-a century after they were written.

Several reasons may explain this disregard. I have already hinted at the gender issues that nurses' accounts of the war brought to the foreground in a manner that was often uncomfortable to the collective mind. As has been demonstrated by a number of scholars (among whom Tylee 1990; Higonnet 1993; Gallagher 1998; Hallett 2013; Acton 2013; Geiger 2015), the accounts of the war by noncombatants, especially women, did not sit well with the public in the immediate afterwar, or even in the following decade. Margaret Higonnet thus examines the resistance to female writing on war experience, both on grounds of "gendered gentility" or "propriety", and because experiencing and representing the war was claimed as a male prerogative:

a woman who undertook this topic might encounter hostility for trespassing on politically reserved terrain. If she wrote realistically, she could face official censorship for producing demoralizing, unpatriotic texts. A veteran, who had risked and perhaps given his life to the nation, might be justified in holding the leaders of the nation to account for the bloodshed it had exacted. But a woman who had not been called upon to make parallel sacrifices, from this point of view, had no right to criticize the very system that protected her. (Higonnet 1993, 207)

My aim here, nevertheless, is to focus on another set of potential causes for the general disinterest in Borden's text for nearly a century-causes that are related to the form that she gave to her testimony. Borden's bold aesthetic choices were indeed the first cause of affront brought forward by critics when The Forbidden Zone was first published. As Laurie Kaplan remarks,

Shocked reviewers found Borden's language too "graphic", the style too experimental, and the scenes in the hospital in general, and in the operating room in particular, hideously "dreadful"1. [...] reviewers balked at the idea of a woman's 
book that described the effects of trauma-that explored "forbidden subjects"2. (Kaplan 36) handled. Laurie Kaplan argues that "as an experimental literary artifact, the book is consciously anticonventional-as anti-conventional as the author herself" (35). Even without considering the exceptional status of its author, The Forbidden Zone stands indeed as an atypical piece of testimony of the First World War, one that does not fit any pre-determined category. Published in 1929, yet predominantly written during the war, in the direct immediacy of the front, it is not a diary, nor a memoir such as those written by Vera Brittain through her Chronicles of Youth and Testament of Youth. Nor is it a collection of poems akin to those written by the well-known War Poets-such as Siegfried Sassoon, Robert Graves, Wilfred Owen, or Isaac Rosenberg. It is not a vast semi-fictional-and semi-autobiographical-narrative of the war either, such as Ford Madox Ford's Parade's End tetralogy (1924-28), Graves's Good-bye To All That (1929), or Sassoon's Memoirs of an Infantry Officer (1930), which were all published around the same time as The Forbidden Zone. In her preface, Mary Borden refers to her texts as "sketches and poems", and to the volume as a "collection of fragments"-adding a few lines further on that they are "fragments of a great confusion" (Borden, "The Preface", n. p.). The Forbidden Zone is indeed a heterogeneous medley of fragments: some in prose such as "The Captive Balloon", yet bearing a strong poetic quality; others in free verse that read almost like prose, such as "The Hill". Most fragments mix landscape, portrait, and narrative. One piece, "In the Operating Room", even reads as a grotesque semimacabre, semi-farcical theatre sketch. Some pieces read like essays, although the majority work as vignettes that offer a disjointed vision of Borden's experience as a war nurse. Max Saunders defines The Forbidden Zone as "memoir by fragment, by impression" (Saunders 181), which emphasizes the text's generic instability. In a letter to her lover, Edward Spears, Borden mentioned one of the first pieces that she wrote for The Forbidden Zone, which was originally published in The English Review in 1917, and foregrounded the equivocal nature of her work: "I'm beginning a sort of poem" ${ }^{3}$ (emphasis mine). Borden also directly addresses this lack of normativity in her preface to the collection, asserting it as inherent in the process of representing the war, and essential to the authenticity of her testimony: "any attempt to reduce the[se impressions] to order would require artifice on my part and would falsify them" (Borden, "The Preface", n. p.). The final piece of the volume, a poem entitled "Unidentified", of which the final word is "unknown", acts as a retrospective metapoetic comment upon the entire volume. Laurie Kaplan has commented on the generic fluidity of The Forbidden Zone, which she argues is analogous to that of Helen Zenna Smith's Not So Quiet...Stepdaughters of War (1930):

In transforming women's war diaries and memoirs into hybridized memoir fictions, Smith and Borden develop a modernist interpretation of the chaos of war reality. This kind of expressive art relies on authentic language and image, not on écriture feminine.' (Kaplan, 37)

11 To Kaplan, the unclassifiable nature of Borden's-and Smith's-texts contributes to their modernist aesthetics. 


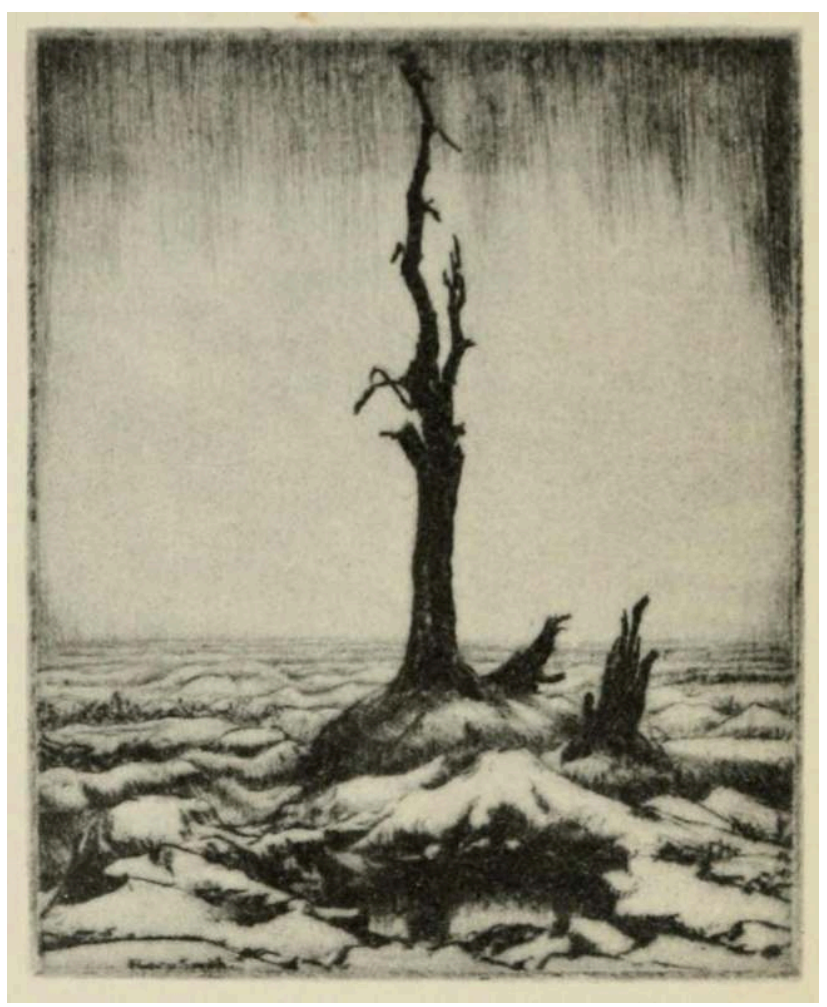

Percy Smith, Solitude

12 The frontispiece of the original volume adumbrates the volume's singularity. This print by Percy Delf Smith, who arrived at the Somme in October 1916 to serve with the Royal Marine Artillery, shows a lone tree standing over a landscape ravaged by war; the caption beneath reads: "The zone at Thiepval, near the Somme, in 1916". The title of the print, Solitude, bolsters the interpretation of the tree as a projection of human experience, intimating the sense that one is irrevocably isolated when experiencing the colossal human destruction enacted in the First World War. In keeping with this prefatory landscape, one of the governing paradigms of the volume is its emphasis on a geographical expression of war experience.

\section{A geography of isolation: a non-place?}

13 The question of trauma narratives, and of the manner in which trauma both impedes and shapes accounts of the war, has been at the heart of much research on World War I writing, especially when it comes to nurse writing. ${ }^{4}$ Another major perspective developed on nurse writers of the war has been, of course, their challenge of traditional gender divides. ${ }^{5}$ Hazel Hutchinson's The War that Used Up Words: American Writers and the First World War (2015) is concerned with Mary Borden, among other American authors who wrote during the war. Its perspective is primarily that of a cultural history of the impact of the war on the American literary scene, and the specificity of the American literary response to the war. It lays cultural groundwork that is most useful for this article, as well as gives an excellent and nuanced overview of The Forbidden Zone. These various approaches have been invaluable to deepen the understanding of nurse writing; however, the purpose of this article is to delineate a phenomenology of the war 
that transcends questions of trauma and categories of gender, and which has tended to be eclipsed by these two perspectives in recent criticism. ${ }^{6}$ The aim is not to oppose the rich criticism that has of late illuminated war writing by nurses, but rather to propose an added, complementary perspective. Examining the phenomenology that emerges from Borden's literary account of the war allows us to focus on the very act of witnessing the war through the senses, and on Borden's attempt to recount this sensory experience and recreate a trace of it in the reading experience. This perspective may also allow us to consider the limits set to humanity through this incommensurate experience. Beyond considerations of gender or trauma, indeed, and notwithstanding their significance, the issue negotiated in these texts is also of an ontological nature. What becomes of the subject experiencing the war? What are the tools at his or her disposal to articulate this experience? And how can the writer recreate a hint of this feeling of ontological disruption within the reader?

These questions are consistently apprehended in Borden's text through the lens of geography. The entire volume abounds in spatial elements. When examining the contents page, for instance, we may notice a striking consistency in the titles of the various fragments, which are often concerned with geography. Part one is thus entitled "The North", part two, "The Somme"; many chapter titles are likewise concerned with spaces, such as "Belgium", "The Beach", "The Square", "The City in the Desert", and "In the Operating Room". These titles denote points on a map, with a zooming-in effect through the first two sections from larger areas-"the North"-to a country -"Belgium"-to smaller and smaller spots, all the way to the indoors scene of "In the Operating Room". This apparent narrowing of the focus, conveying an impression of increasing geographical precision, comes into tension with the overall title, The Forbidden Zone, and more generally with the entire paratext opening the volume. Borden dedicated the collection "to the Poilus who came that way in 1914-1918" (emphasis mine); beyond its indeterminacy, the demonstrative "that" implies an unbridgeable distance from the reader. Both the title and the dedication hint at a space that cannot be outlined precisely-a space that is not even supposed to exist, as this "zone" is "forbidden". This zone is also unstable and constantly redefined, since the field hospitals moved along with the location of the armies-as is underscored by the first two sections of the volume, "Part One: The North" and "Part Two: The Somme", which outline the progress of Borden's hospital along the line, following the troops' movement. Borden devotes a full paragraph in her short Preface to address this peculiar space:

I have called the collection of fragments The Forbidden Zone because the strip of land immediately behind the zone of fire where I was stationed went by that name in the French Army. We were moved up and down inside it; our hospital unit was shifted from Flanders to the Somme, then to Champagne, and then back again to Belgium, but we never left La Zone Interdite.

Significantly, further down in the preface, Borden articulates her inability to express her experience accurately in geographical terms: "I have blurred the bare horror of facts and softened the reality in spite of myself, not because I wished to do so, but because I was incapable of a nearer approach to the truth" (emphasis mine).

Throughout the collection, there persists a tension between geographical precision and indefiniteness. A number of fragments open on an attempt at mapping out the war experience: the ability to grasp events geographically may appear as a means to give a modicum of control to the experience. The collection is concerned not just with the 
effect of the war on humanity, but also on the land where it takes place. Geography develops as a prevalent theme within most of the pieces, one that leads to moments of suspended beauty, as in the beginning of "Bombardment", which is strongly redolent of Georgian pastoral poetry, albeit with a strong ironical undertone:

The wide sweet heaven was filling with light: the perfect dome of night was changing into day. A million silver worlds dissolved from above the earth: the sun was about to rise in stillness: no wind stirred. (Borden 5)

However, whilst there is a manifest attempt to firmly anchor the various sketches in space, this effort is challenged and eventually counteracted by a growing vagueness, as in "The City in the Desert": with its two nouns denoting places, its spatial preposition and two definite articles, the title demonstrates an emphasis on topography; however, the very question on which the piece opens dismisses any hope of precision that the reader may have held: "What is this city?" Further down, this indeterminacy is made final by the name-or lack thereof-of the place:

That flimsy gate with a banner across it as if for celebration, with H.O.E. 32 on it in big black letters, and a flag flying, and those red crosses painted on the iron roofs of the building. H.O.E. 32 must be the name of the place; but why such a name? What does it mean? (Borden 112)

The initials refer to Hôpital d'Evacuation, as was customary during the war, but the meaning is blurred by the process of distanciation and defamiliarisation. Such indeterminacy operates as a metatextual reflection on the text that has a direct impact on the reading experience: via this defamiliarising process, the reader is herself positioned in a non-place, where any hope of stable orientation is defeated.

Borden's rhetoric of suppression is made immediately manifest from the very first piece in The Forbidden Zone, "Belgium"; its first few paragraphs set the tone for the collection as a whole, and are concerned here as well with geography:

On our right? That's the road to Ypres. The less said about that road the better: no one goes down it for choice-it's British now. Ahead of us, then? No, you can't get out that way. No, there's no frontier, just a bleeding edge, trenches. That's where the enemy took his last bite, fastened his iron teeth, and stuffed to bursting, stopped devouring Belgium, left this strip, these useless fields, these crumpled dwellings.

Cities? None. Towns? No whole ones. (Borden 1-2)

The reticence inherent in the phrase "The less said about that road the better" introduces the representational aporia already brought forward in Borden's prologue. The description of the frontline as "a bleeding edge" epitomises Borden's topography of war. Not only can she only access-and therefore only render-the periphery of war; but this "edge" implies a void, a chasm, and portrays the persona, and consequently the reader, as standing on the brink. If we adopt a medical perspective, it may also be intended by the nurse as a comparison of the trenches with an amputated limb. Borden's geography of lack is most obviously conveyed by the accumulation of forms of negation; yet surprisingly, these negations open out onto a more loquacious few lines, with pairs of adjectives and nouns, thus implying a greater precision: "bleeding edge", "last bite", "iron teeth", "useless fields", "crumpled dwelling". In a process somewhat akin to Blanchot's poetics of negativity, it seems that naming absence allows to free up speech. The extended metaphor of the enemy as a metallic, futuristic beast-the influence of Futurism is palpable-sounds almost lyrical. The combined devices of asyndeton and accumulation generate a sentence that keeps growing, feeding on itself, 
in a way akin to that of the enemy feeding off Belgium. Representation, nonetheless, is once again at a loss in the next sentence: "Cities? None. Towns? No whole ones". The desertion of syntax, the use of monosyllables, and the negations are echoed by the use of a minimal variety of sounds, where the initial /i/ sounds are quickly engulfed by a long series of deep /o/ sounds.

21 The aporia inherent in the direct articulation of war experience has been much discussed in terms of an inability to confront trauma. From a purely phenomenological perspective, this negative mode of representation also works as a powerful way for Borden to recreate in the reader a hint of the feeling of standing helplessly outside the events that was at the core of the nursing experience. For the carers, the violence of the war was witnessed not at first hand, through the direct impact of shells and weapons, but secondarily, and often through what was lacking in the landscapes or in the bodies that were brought to them: through the absence of limbs, of faces, of sight, as is constantly portrayed in The Forbidden Zone. Borden's descriptions are thus consistently marked with negativity. The soldiers under her care are no longer whole, no longer men, but a sum of what has been damaged in them; they are portrayed as a sum of their lacks:

There are no men here, so why should I be a woman? There are heads and knees and mangled testicles. There are chests with holes as big as your fist, and pulpy thighs, shapeless; and stumps where legs once were fastened. There are eyes-eyes of sick dogs, sick cats, blind eyes, eyes of delirium; and mouths that cannot articulate; and parts of faces-the nose gone, or the jaw. There are these things, but no men [...]. (Borden 60)

Borden's poetics of negativity generates a potent spectrality throughout her descriptions. The rhetoric of loss and indirection produces in turn a hazy experience in the reader-one that may be felt as frustrating, and perhaps contributed to the difficult rise of interest in this text; but one that was inherent, although in a vastly more intense and violent form, in the phenomenology of the war for the non-combatant carers.

\section{Transitional spaces}

23 Along with this lack of determinacy, the spaces in Borden's sketches are generally transitional: they are often beaches, interfaces between the earth and the sea, such as in "Bombardment", or "The Beach"; there are also many windows through which the focaliser gazes out at the war, as an outsider, as in "The Square", "The City in the Desert", and "Moonlight". The field hospital itself is a liminal space, as is delineated at the end of the Preface: "I have dared to dedicate these pages to the poilus who passed through our hands during the war" (emphasis mine).

Jasie Stokes astutely proposes a correspondence between the space's negativity and its transitional quality, drawing from Marc Augé's definition of non-space:

We may characterise The Forbidden Zone then as a "non-place", a concept which, as Marc Augé theorises, "designates two complimentary but distinct realities: spaces formed in relation to certain ends (transport, transit, commerce, leisure) and the relations that individuals have with these spaces", relations marked by solitary movement through and within the space ([Augé] 94). The Forbidden Zone is a nonanthropological and non-historical space, characterised by its temporary function during the war as a space of transit and movement, a constantly fluctuating landscape of roads and mobile hospitals. (Stokes 118-19) 
transitional quality of space is reverberated in the position of the nurse persona who inhabits this Forbidden Zone. Each text delivers a vignette exploring the interstitial stance of the nurse, suspended between the civilian world and the army, the sound and the wounded, the living and the dead, the men and the women, without truly belonging to either group. Ariela Freedman outlines this liminality:

Borden's choice to portray the nurse and the male patient in these stories, rather than the civilian woman and the active combatant, situates her in a sequestered zone between the home front and the front line, as well as between traditionally gendered roles. (Freedman 121)

This interstitial stance is particularly manifest in "The Regiment", where the lone figure of the nurse is poised between the separate groups formed by the regiment, the officers, and the townspeople. The reader is made to enter into the collective minds of the soldiers and the townspeople through the stream of consciousness technique, and the narrative even enacts a mute-albeit arduous-dialogue between the various groups taking part in the scene:

The town shuddered. But there was sympathy between the regiment and the town.

The town said to the regiment:

"You old ones, you are strangers; but we know you. You come from the war. You are welcome."

The regiment said to the town:

"You are kind, but you'd do well to keep your welcome for those who can use it. We are old. We want nothing since we cannot go home." (Borden 32-33)

In contrast, when the nurse enters the scene, she stands as an individual, whilst all the other protagonists are depicted collectively as unified groups, each endowed with a collective mind; and she cannot enter into a dialogue with either the town, or the regiment:

Her shadowy eyes said to the regiment: "I came to the war to nurse you and comfort you."

The regiment said nothing. It did not know what to say. It was merely puzzled. [...]

To the regiment the woman was a puzzle, but the old ones were too tired to bother about puzzles.

To the town she was a strange fantastic thing, like a white peacock. (Borden 34-35)

The plural "we" and "you" in the first dialogue is replaced with the singular "I" and "she". The nurse is an exception among the characters of the war, just as the area where she works, this forbidden zone, is an a-topia within the landscape of war. Where the initial dialogue enacts an acknowledgement of the other group's alterity, and thus of their humanity, the nurse is animalised and objectified: she is "a beautiful animal" (34) and "a puzzle" to the regiment, and "a strange fantastic thing, like a white peacock" (35), to the town (emphasis mine).

Nonetheless, some rare moments of connection stand out in Borden's sketches, between the categories of combatant and carer, dying and non-dying, that defy the isolation of individuals; but these moments are sensed as threatening, as Ariela Freedman remarks,

Each of these subject positions most often excludes the possibility of connection, such that when connection does occur, it creates the exception that threatens the whole edifice of the war. (Freedman 121; emphasis mine)

In the phenomenology of war that is established in The Forbidden Zone, the extreme unfamiliarity of the war experience, its exceptional character, becomes the accepted norm, as a condition for the survival of the subject. Conversely, the familiar and trivial 
situations of life outside the war are turned into the exception in this world cut off from civilian existence, and are sensed as intolerable: they jeopardise the integrity of the system developed on the frontline and in the forbidden zone, and thus threaten to reactivate within the subject the awareness of an alternate form of life, outside of war, that would make his or her current experience unbearable by contrast. This inversion between the familiar and the extraordinary is made particularly clear in the piece entitled "Moonlight", where the nurse persona muses on the whole of life experience as being contained in war:

The other world was a dream. Beyond the gauze curtains of the tender night there is War, and nothing else but War. Hounds of war, growling, howling; bulls of war, bellowing, snorting; war eagles, shrieking and screaming; war fiends banging at the gates of Heaven, howling at the open gates of hell. There is War on the earthnothing but War, War let loose on the world, War-nothing left in the whole world but War-War, world without end, amen. (Borden 57-58)

This passage is strongly redolent of the Book of Revelation, where four animals guard the throne of God:

And in the midst of the throne, and round about the throne, were four beasts full of eyes before and behind. And the first beast was like a lion, and the second beast like a calf, and the third beast had a face as a man, and the fourth beast was like a flying eagle. And the four beasts had each of them six wings about him; and they were full of eyes within: and they rest not day and night, saying, Holy, holy, holy, Lord God Almighty, which was, and is, and is to come. (The Bible, Authorized King James Version, Rev. 4:6-8)

It is probable that this apocalyptic vision was more or less consciously influenced by Mary Borden's mother, who was a member of a fundamentalist church and whose uppermost concern throughout her adult life was the issue of salvation, of the original sin and of the Final Judgement. Borden's testimony of the war her takes on definite accents of sacrality, in keeping with Max Saunders's analysis of the process of testimony. Reading The Forbidden Zone along the concept of testimony theorised by Shoshana Felman (1991), Saunders argues:

War writing [...] moves between [...] two rhetorical poles: on the one hand, documentary realism that seeks to represent the facts; to bear witness; to give testimony. But, on the other hand, this is always already bound up with sacralization. As Felman argues, a testimonial attitude comes from feeling the event is in excess; that it is a mystery. (Saunders 188)

Borden's text takes on an incantatory quality, through the hammering recurrence of the word "War", replacing the iteration of "holy" in the Book of Revelation, and which is capitalised in a manner that assimilates it to a Biblical or mythological figure. The quick shift from the past to the present tense, along with the accumulation of nominal phrases paired with present participles, excludes temporality from the description. The present tense thus gains a gnomic quality-no longer pointing at a specific situation in space and time, but describing an immutable state. The incantatory character of the passage is reinforced by its strong musicality, through the recurrence of /w/ sounds prolonging the initial consonant of "war" in other words: "world", "growling", "howling", "bellowing", "without". The onomatopoeic power of the numerous verbs denoting sounds-"growling, howling", "bellowing, snorting", "shrieking and screaming", "banging"-creates an aural association of the word "War" with the apocalyptic sounds of the animals mentioned. The closing "amen" reinforces the finality of the tirade. Yet the persona remains in a liminal position: standing silent and 
motionless behind "the gauze curtains", she watches and listens to the war from the edge.

\section{Conclusion}

Borden's war writing challenges not only the cultural norms of the idealised, sanctified nurse figure, but also the aesthetic conventions of what was expected of nurses' accounts during the war and in the post-war decades. The liminal and spectral mode of representation generates a puzzling and disorienting experience for the reader, which probably contributed to the lack of interest in this text until recently. Beyond the question of war writing, however, this process of displacement and lack can be considered as the very condition of literature, as is outlined by Derrida:

Here is a departure from the world toward a place which is neither a non-place nor an other world, neither a utopia nor an alibi [...] This emptiness as the situation of literature must be acknowledged by the critic as that which constitutes the specificity of his object, as that around which he always speaks (Derrida 1978, 7-8). ${ }^{7}$ the bare essence of literature, when writing is divested of any familiar geographical, cultural and aesthetic landmark.

\section{BIBLIOGRAPHY}

The Bible. Authorized King James Version. Oxford: Oxford University Press, 1998.

Acton, Carol. "Diverting the Gaze: The Unseen Text in Women's War Writing." College Literature 31:2 (2004): 53-79.

---. “Negotiating Injury and Masculinity in First World War Nurses' Writing." In First World War Nursing: New Perspectives. Eds. Alison Fell and Christine Hallett. London: Routledge, 2013. 123-138.

---. “Their Wounds Gape at me': First World War Nursing Accounts and the Politics of Injury.” In Living War, Thinking Peace (1914-1924): Women's Experiences, Feminist Thought, and International Relations. Eds. Bruna Bianchi and Geraldine Ludbrook. Newcastle upon Tyne: Cambridge Scholars Publishing, 2016. 44-63.

Acton, Carol and Jane Potter. “'These frightful sights would work havoc with one's brain': Subjective Experience, Trauma, and Resilience in First World War Writings by Medical Personnel." Literature and Medicine 30:1 (Spring 2012): 61-85.

---. Working in a world of hurt: Trauma and resilience in the narratives of medical personnel in warzones. Manchester: Manchester University Press, 2015.

Augé, Marc. Non-places: Introduction to an anthropology of Supermodernity. London: Verso, 1995.

Borden, Mary. The Forbidden Zone. London: Heinemann, 1929.

Conway, Jane. Mary Borden: A Woman of Two Wars. London: Munday Books, 2010. 
Derrida, Jacques. L'écriture et la différence. Paris: Seuil, 1967.

---. Writing and Difference. Trans. Alan Bass. Chicago: University of Chicago Press, 1978.

Fell, Alison and Christine Hallett (eds.). First World War Nursing: New Perspectives. London: Routledge, 2013.

Felsman, Shoshana and Dori Laub. Testimony: Crises of Witnessing in literature, Psychoanalysis, and History. London: Routledge, 1991.

Freedman, Ariela. “Mary Borden's Forbidden Zone: Women's Writing from No-Man's-Land.” Modernism/modernity 9:1 (2002): 109-124.

Gallagher, Jean. The World Wars through the Female Gaze. Carbondale: Southern Illinois University Press, 1998.

Geiger, Maria. "No trench required: validating the voices of female poets of WWI." War, Literature and The Arts 27: 1 (2015): n. p.

Gilbert, Sandra. "Soldier's Heart: Literary Men, Literary Women, and the Great War." In Behind the Lines: Gender and the Two World Wars. Eds. Margaret Higonnet, et al. New Haven: Yale University Press: 1987. 197-226.

--- and Susan Gubar. No Man's Land: The War of Words. New Haven: Yale University Press, 1989. Grayzel, Susan R. and Proctor, Tammy M (eds). Gender and the Great War. Oxford: Oxford University Press, 2017.

Hallett, Christine E. Containing Trauma: Nursing Work in the First World War. Manchester: Manchester University Press, 2009.

---. Nurse Writers of the Great War. Manchester: Manchester University Press, 2016.

Higonnet, Margaret R., Jane Jenson, Sonya Michel, Margaret Collins Weitz (eds.). Behind the Lines: Gender and the Two World Wars. New Haven: Yale University Press, 1987.

Higonnet, Margaret R. “Not so Quiet in No-Woman's-Land”. In Gendering War Talk. Eds. Miriam Cooke and Angela Woollacott. Princeton: Princeton University Press, 1993. 205-226.

---. (ed.). Lines of Fire: Women Writers of WWI. Harmondsworth: Penguin, 1999.

---. "Authenticity and Art in Trauma Narratives of World War I" Modernism/Modernity 9:1 (2002): 91-107.

Kaplan, Laurie. "Deformities of the Great War: The Narratives of Mary Borden and Helen Zenna Smith." Women and Language 27:2 (2004): 35-43.

Kelly, Alice. Commemorative Modernisms: Women Writers, Death and the First Word War. Edinburgh: Edinburgh University Press, 2020.

La Motte, Ellen. The Backwash of War. New York and London: G.P. Putnam's Sons, 1916.

Mortimer, Maud. A Green Tent in Flanders. New York: Doubleday, Page \& Co, 1917.

Saunders, Max. "War Literature, Bearing Witness, and the Problem of Sacralization: Trauma and Desire in the Writing of Mary Borden and Others." In Memories and Representations of War: The Case of World War I and World War II. Eds. Elena Lamberti and Vita Fortunati. Amsterdam: Brill, 2009. 177-192.

Stokes, Jasie. "Fragments of a Great Confusion: Abjection, Subjectivity, and the Body in Mary Borden's The Forbidden Zone". In Corporeality and Culture: Bodies in Movement. Eds. Karin Sellberg, Lena Wånggren, and Kamillea Aghtan. Oxford: Routledge, 2015. 115-26. 
Tylee, Claire. The Great War and Women's Consciousness: Images of Militarism and Womanhood in Women's Writings 1914-64. Iowa City: University of Iowa Press, 1990.

Warner, Agnes. My Beloved Poilus. St. John, N.B: Barnes, 1917.

\section{NOTES}

1. See for example the Times Literary Supplement, December 5, 1929, Saturday Review of Literature, July 26, 1930.

2. Higonnet, Behind the Lines, 15.

3. August 1917, quoted in Conway 77.

4. See for instance Higonnet 2002; Hallett 2009; Acton and Potter 2012, 2015; Fell and Hallett 2013. 5. See for instance Geiger 2015 ; Gilbert 1987; Higonnet 1987; Gilbert and Gubar 1989; Tylee 1990; Higonnet 1993; Gallagher 1998; Grayzel and Proctor 2017.

6. Alice Kelly's recent and fascinating monograph on women writing of death in the context of the First World War (2020) is concerned with questions of aesthetics, but it does not examine Borden's text in detail.

7. Original text : "Il s'agit [...] d'une sortie hors du monde, vers un lieu qui n'est ni un non-lieu ni un autre monde, ni une utopie ni un alibi. [...] Vacance comme situation de la littérature, [...] autour de laquelle on parle toujours" (Derrida 1967, 17).

\section{ABSTRACTS}

This essay focuses on the experience and literary testimony of Mary Borden, an outstanding figure in the landscape of World War I nursing. Beyond gender issues or questions of traumatic writing, what emerges out of Borden's disjointed sketches is a phenomenology of the exceptional experience of war. Borden's war writing sets itself at odds with cultural and aesthetic norms, challenging not only the model of the idealised, sanctified nurse figure, but the aesthetic expectations of nurses' accounts.

Cet article traite de l'expérience personnelle et du témoignage littéraire de Mary Borden, une figure singulière parmi les infirmières anglophones de la Première Guerre mondiale. Par-delà les questions de genre ou d'écriture du trauma, c'est une phénoménologie de l'expérience de la guerre sans précédent qui émerge des esquisses disjointes de Borden. Son témoignage littéraire de la guerre se dissocie des normes culturelles et esthétiques, en battant en brèche non seulement le modèle de la figure de l'infirmière idéalisée et sanctifiée, mais aussi les attentes esthétiques sur les écrits d'infirmières.

\section{INDEX}

Keywords: negativity, phenomenology, space, war, war nursing, World War I

Mots-clés: espace, infirmière de guerre, guerre, négativité, phénoménologie, Première Guerre mondiale 


\section{AUTHORS}

\section{ISABELLE BRASME}

Maîtresse de conférences

Université Paul Valéry Montpellier 3

isabelle.brasme@univ-montp3.fr 